\title{
Linked Data
}

compiled by Anna Appleman

Davis, Kelly. 2019. "Old Metadata in a New World: Standardizing the Getty Provenance Index for Linked Data." Art Libraries Journal 44, no. 4 (October): 162-6.

Diane, Rasmussen Pennington and Laura Cagnazzo. 2019. "Connecting the Silos." Journal of Documentation 75, no. 3: 643-6.

Díaz-Corona, Dayany, Javier Lacasta, Miguel Ángel Latre, F. Javier Zarazaga-Soria, and Javier Nogueras-Iso. 2019. "Profiling of Knowledge Organisation Systems for the Annotation of Linked Data Cultural Resources.” Information Systems 84 (September): 17-28.

González, Pedro Urra. 2019. "A Strategy for Integrating Printed Catalog Cards from Three Cuban Libraries into the Open Linked Data Space." Library Trends 67, no. 4 (Spring): 713-28.

Anna Appleman is Cataloger at Columbia Theological Seminary. 